Acta Theriologica 39 (1): 13-19, 1994.

PL ISSN 0001-7051

\title{
Biogen content in roe deer Capreolus capreolus antlers and skulls
}

\author{
Tomasz PIS, Marta CICHOŃSKA, Wiesław DUDZIŃSKI and Andrzej GÓRECKI
}

Pis T., Cichońska M., Dudziński W. and Górecki A. 1994. Biogen content in roe deer Capreolus capreolus antlers and skulls. Acta theriol. 39: 13-19.

Antlers and skulls collected for chemical analysis originated from roe deer Capreolus capreolus (Linnaeus, 1758) bucks bagged in the Rogów hunting district in central Poland. Antlers were divided by the quality and by the age. The specific gravity of the antlers as well as nitrogen, calcium, phosphorus, magnesium and sodium content were measured. The highest nitrogen content was in corkscrew antlers, which also had the lowest density. Corkscrew antlers contained the lowest calcium, phosphorus, magnesium and sodium content. The highest amounts of these biogens were found in regressive and year-old antlers. $\mathrm{Ca} / \mathrm{P}$ ratios were measured and relatively consistent, while $\mathrm{Ca} / \mathrm{N}$ ratios varied and were lowest in year-old antlers.

Institute of Environmental Biology, Jagiellonian University, 30-060 Kraków, Ingardena 6, Poland (TP, MC, AG); Department of Game Management, Agricultural University of Warsaw, 02-528 Warsaw, Rakowiecka 26/30, Poland (WD)

Key words: Capreolus capreolus, antlers, biogens, skulls

\section{Introduction}

One result of man's ever-increasing intervention in the natural environment is disturbance of biogens cycling, producing insufficiencies or excesses of certain biogens in living organisms. The harmful effects of human activities are observed in nearly every ecosystem.

Such a situation has been noted in one of the forest game districts in central Poland. Among roe deer Capreolus capreolus (Linnaeus, 1758) bagged in the district, besides specimens with properly formed antlers, deer have been sighted frequently with antlers that lacked pearls, were twisted in irregular spiral patterns, had atypical coloration, sizes, and shapes.

The chemical composition of normal, fully developed antlers is similar to the chemical composition of skeletal bone. Organic substances comprised mainly of protein account for approximately $44 \%$ of antler mass; the other $56 \%$ is mostly an inorganic substance in which calcium, phosphorus and magnesium compounds prevail (Pielowski 1988).

Growth processes and mineralization of antlers are regulated by both nervous and hormonal mechanisms (Bubenik and Bubenik 1990). The shape, size and 
quality of antlers depends on the animal's genotype and on environmental factors, mainly climate and food availability (Suttie and Fennessy 1991). Food supplemented with protein and mineral salts appears to have a decisive influence on antler growth and ossification (Pielowski 1988).

In order to determine the cause of the antler malformation in roe deer bucks the chemical composition and the specific-gravity of malformed and well-developed antlers were compared. The following biogens concentration involved in the mineralization process: calcium, phosphorus, magnesium, sodium, and nitrogen as an indicator of total protein content were analyzed.

\section{Material and methods}

The antlers and skulls studied were obtained from roe deer bucks bagged in small woods in Rogów (central Poland: $51^{\circ} 48^{\prime} \mathrm{N}$; $19^{\circ} 53^{\prime} \mathrm{E}$ ).

The antlers were grouped into age classes (1-year, 2-years, 3-4 years and 5-9 years), and also quality classes that delineated the following kinds of antler shapes:

- properly formed antlers, of typical shape, branching, with discernible pearls,

- partially malformed antlers, with traits intermediate between normal and completely deformed,

- deformed or corkscrew antlers, of an irregular shape, with spiral-shaped cones and usually without pearls,

- regressive antlers, without pearls but with other traits typical of properly formed antlers.

To obtain homogenous samples, the antlers were converted to shavings and divided into two categories: (1) lower, at the base; (2) upper or apical. Year-old antlers and regressive antlers, which were shaved down, were an exception.

About $1 \mathrm{~g}$ samples of antlers and skulls were demineralized in concentrated sulfuric acid (for nitrogen and phosphorus measurement) and a 4:1 mixture of nitric and chloride acids (for calcium, magnesium and sodium). Kjeldahl's method of potentiometric titration was employed in for determining total nitrogen (Szczepaniak 1985) and a SPECTROMOM 204 colorimeter was used to determine phosphorus by spectrophotometry. Biogenic metal ( $\mathrm{Ca}, \mathrm{Mg}$ and $\mathrm{Na}$ ) content was measured by spectrophotometric atomic absorption method in the flame burner of an IL-251 spectrophotometer.

Standard deviation (SD), mean $(\bar{x})$ and the Dixon test were employed to eliminate extreme statistical results burdened by gross errors. Kruskal-Wallis non-parametric and a posteriori tests (Sachs 1984) were employed to ascertain the significance of biogen content differences among the quality and age classes of antlers and skulls, as well as differences between the upper and lower antler parts.

\section{Results}

There were significant differences $(p<0.001$ and $p<0.05)$ in specific gravity between the particular antler quality classes, except for properly formed and partially malformed antlers (Table 1). Corkscrew antlers had the lowest density and regressive antlers had the highest (Table 1). Year-old antlers had significantly higher $(p<0.05)$ specific gravity than those in older animals (Table 1 ).

The highest nitrogen concentration was in corkscrew antlers, significantly differing $(p<0.01$ and $p<0.05)$ from the remaining quality groups (Table 2 ). Year-old antlers had the lowest nitrogen content (Fig. 1). Total nitrogen content 
Table 1. Specific gravity of roe deer antlers in $\mathrm{g} / \mathrm{cm}^{3}$ (mean and SD). The levels of statistic differences between classes marked by letters were as follows: $p<0.001$ for a-c, c-d; $p<0.05$ for a-d, b-c, b-d, e-g, e-h.

\begin{tabular}{lrc}
\hline & $n$ & Specific gravity \\
\hline Antler-quality classes & & \\
Normal & 6 & $1.63 \pm 0.090 \mathrm{a}$ \\
Partly malformed & 4 & $1.62 \pm 0.135 \mathrm{~b}$ \\
Corksrew-type & 8 & $1.45 \pm 0.100 \mathrm{c}$ \\
Regressive & 3 & $1.85 \pm 0.168 \mathrm{~d}$ \\
Age classes & & \\
1-year & 5 & $1.84 \pm 0.191 \mathrm{e}$ \\
2-years & 4 & $1.66 \pm 0.327 \mathrm{f}$ \\
3-4 years & 10 & $1.56 \pm 0.119 \mathrm{~g}$ \\
5-9 years & 7 & $1.60 \pm 0.133 \mathrm{~h}$ \\
\hline
\end{tabular}

Table 2. Biogen content in roe deer antlers and skulls (mean and SD) according to antler-quality classes. The levels of statistic differences between classes marked by letters were as follows: $p<0.001$ for A-C, C-D, K-k, O-P; $p<0.01$ for G-g, K-L, J-j, M-O, M-P, N-P; $p<0.05$ for B-C, B-D, N-O, Q-S, S-T.

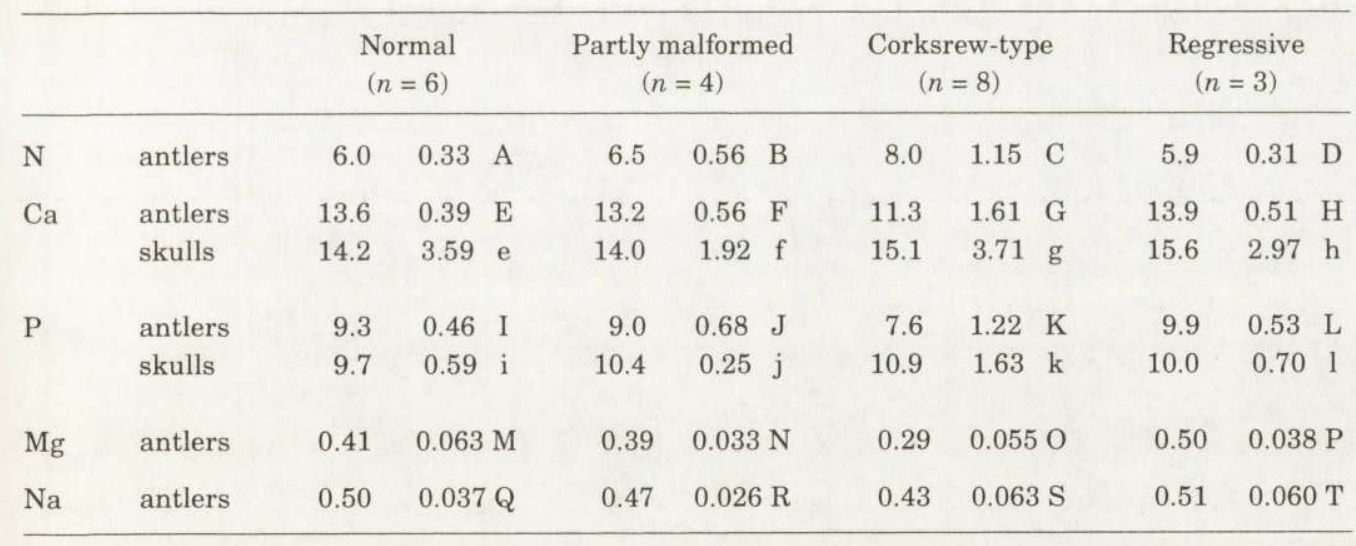

in properly formed antlers averaged $6 \%$ of dry mass. Multiplying that value by a coefficient of 6.25 (Ruszczyc 1963), protein content was calculated at $37.5 \%$ of dry mass.

Calcium content was characterized by an inverse relationship between antlers and skulls. The highest calcium amount was found in year-old antlers; their skulls contained the lowest amount of this biogen (Fig. 1). The opposite was true of corkscrew antlers (Table 2).

As with calcium, phosphorus in corkscrew antlers was significantly $(p<0.001$ and $p<0.01)$ lower than in the other antler types and in their respective skulls 


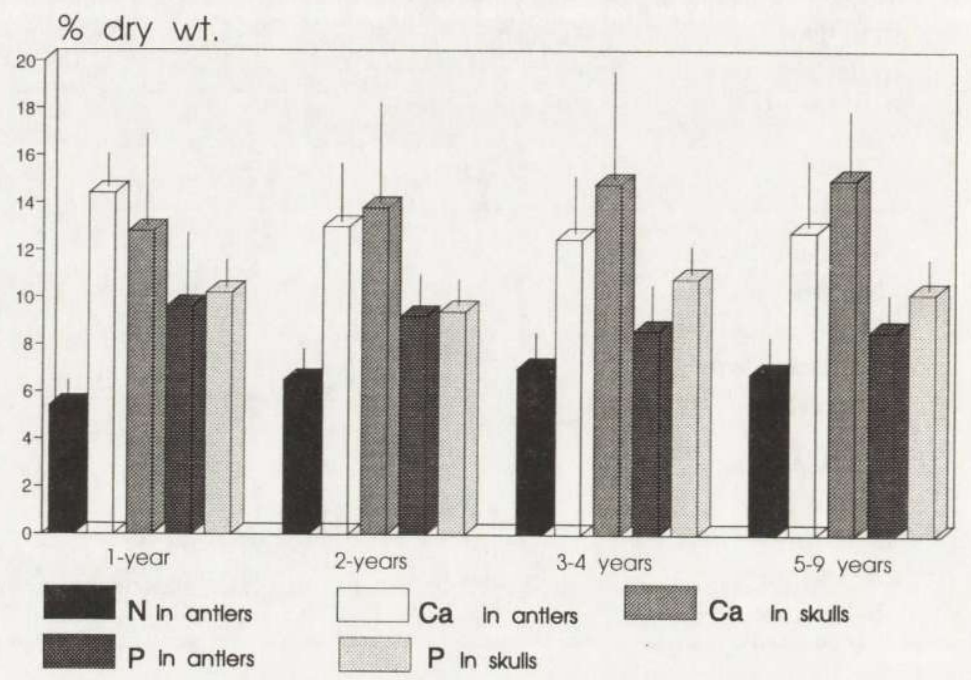

Fig. 1. Nitrogen, calcium, and phosphorus content (per cent of dry wt) in roe deer antlers and skulls (mean and SD) of different age classes.

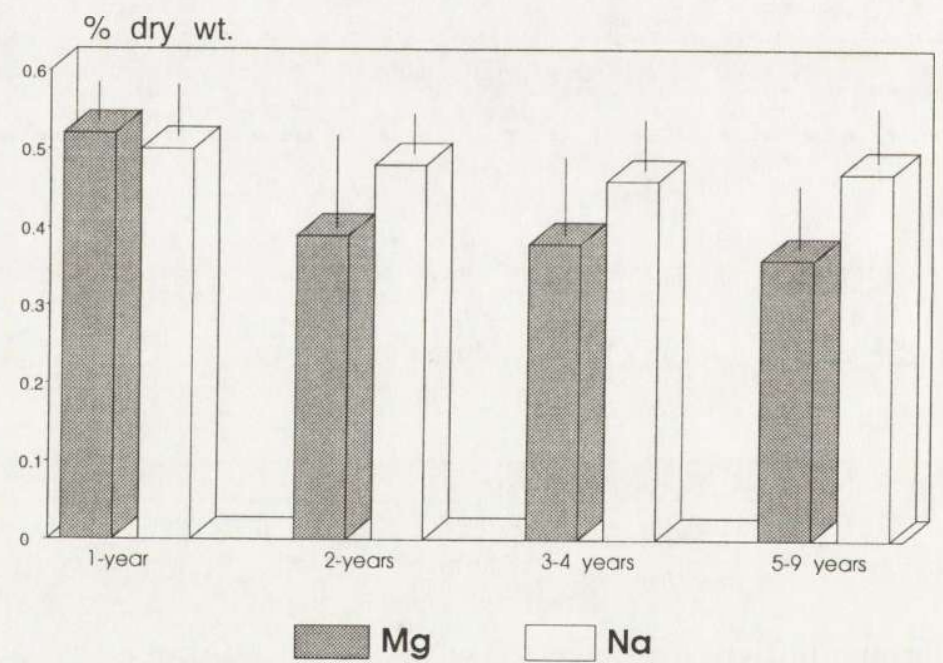

Fig. 2. Magnesium and sodium content (per cent of dry wt) in roe deer antlers (mean and SD) depending on age.

$(p<0.001)$ (Table 2). In addition, phosphorus content in partially malformed antlers significantly differed from that in skulls of the same group $(p<0.01)$ (Table 2 ). Antlers and skulls in the two oldest age groups significantly differed in this regard as well $(p<0.001)$ (Fig. 1). 


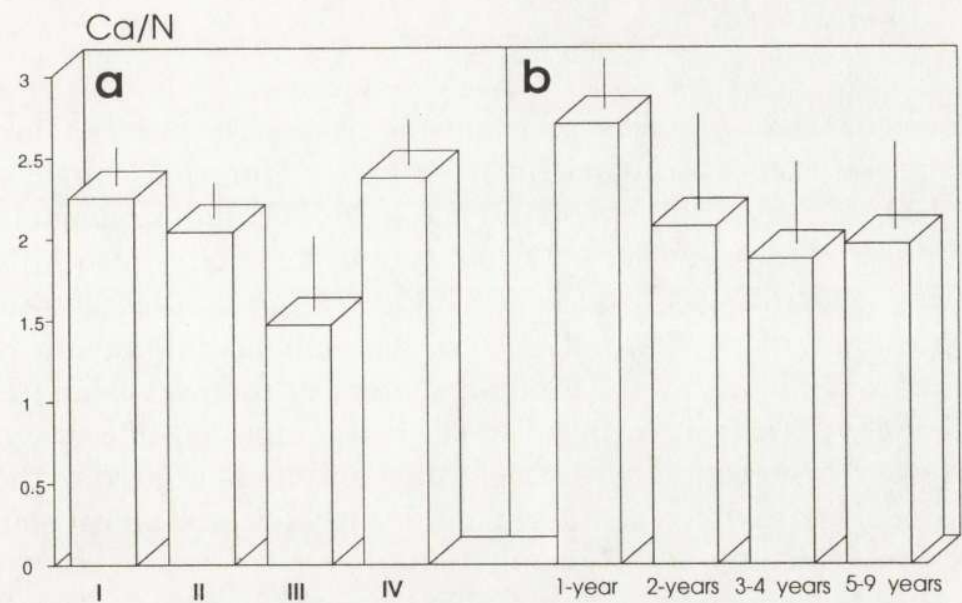

Fig. 3. $\mathrm{Ca} / \mathrm{N}$ ratio in roe deer antlers (mean and $\mathrm{SD}$ ): a - antler quality classes: $\mathrm{I}$ - normal antlers, II - partly malformed, III - corksrew-type, IV - regressive antlers; b - age classes.
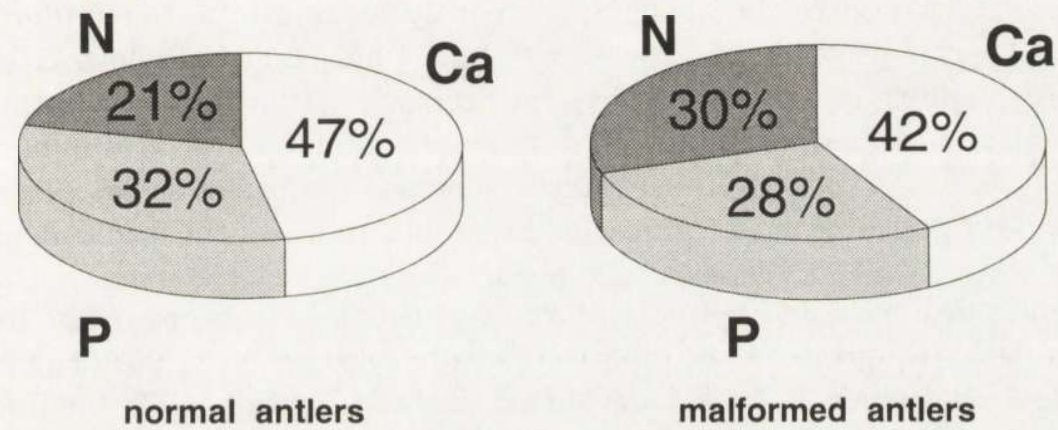

Fig. 4. Percentages of $\mathrm{N}, \mathrm{Ca}$, and $\mathrm{P}$ in properly formed and malformed antlers of roe deer.

Magnesium content and sodium content were similar in all groups. The lowest content of both biogens was observed in corkscrew antlers, and the highest in year-old antlers $(p<0.001, p<0.01$ and $p<0.5$ ) (Table 2, Fig. 2).

No significant differences in the concentrations of any biogens studied were observed between the apical and lower parts of the antlers.

Within all groups the $\mathrm{Ca} / \mathrm{P}$ ratio in antlers and skulls remained relatively stable (mean $=1.45)$, and the differences were statistically insignificant.

The $\mathrm{Ca} / \mathrm{N}$ ratio was lowest in corkscrew antlers $(p<0.001$ and $p<0.05)$ and highest in the year-old antler class $(p<0.001$ and $p<0.01)$ (Fig. 3 ).

Nitrogen, calcium and phosphorus values were grouped into properly formed and malformed antlers (Fig. 4), based on the assumption that these elements comprise $100 \%$ of antler contents. It was determined that deformed antlers contain approximately $50 \%$ protein and properly formed antlers $35.5 \%$. 


\section{Discussion}

A fully developed deer antler is made of bone tissue. The external layer consists of compact bone with Haversian lamellae. The antler's interior is filled with porous spongiform bone. The arrangement of these layers and proportions of their contribution determine an antler's durability and elasticity, also influencing its specific gravity, which ranges between 1.67 and $1.78 \mathrm{~g} / \mathrm{cm}^{3}$ (Jaczewski 1981). The higher mineral content of year-old antlers with an accompanying decrease in nitrogen content, is caused by the greater amount of compact bone in relation to spongiform bone, which in turn is reflected in the high specific gravity of those antlers (Table 1). The lower density of deformed antlers is related to the increased role of spongiform bone, which contains significantly fewer mineral elements than the external part (Bubenik and Bubenik 1990).

Proper antler development depends directly on the organism's calcium/phosphorus metabolism, requiring an appropriate calcium/phosphorus proportion which, according to Bernard (1963), ranges between 1.98 and 2.17. Generally, lower coefficients were obtained in this study. Insufficient nourishment interferes with calcium/phosphorus metabolism, frequently leading to antler underdevelopment and sometimes producing corkscrews, sheephorns, etc. (Pielowski 1988).

The chemical composition and physical properties of antlers depend upon the stage of development and on the particular part under study (Chapman 1975). Bernard (1963) stated that red deer antler biomass contained $34.5 \%$ protein, and after calculating for dry mass he provided results similar to those obtained in this study for properly formed antlers (Table 2).

According to Bernard (1963), calcium and phosphorus content in the dry mass of antlers from 8 species of cervids totaled an average of $21.05 \%$ calcium and $10.08 \%$ phosphorus. In normally developed antlers of adult bucks in Rogów the comparable values were much lower, especially with regard to calcium; the values for biogens in skulls did not essentially differ (Table 2). Magnesium and sodium content in the material from Rogów is similar to the results obtained by Ullrey et al. (1975) for white-tailed deer.

Biogens had an obvious effect on roe deer antler formation. Generally, malformed antlers contained lower amounts of calcium, phosphorus, magnesium and sodium, with higher nitrogen, compared to normally developed antlers (Table 2). The above levels of biogens found in malformed antlers indicate the decreased role of the highly mineralized external layer in these antlers (Bubenik and Bubenik 1990). It was confirmed by the low $\mathrm{Ca} / \mathrm{N}$ ratio (Fig. 3 ) and by the high proportion of nitrogen in the group of the three main biogens (Fig. 4).

Both biogen content and antler gravity in partially malformed antlers were intermediate between properly formed and malformed antlers (Table 2).

Various physico-chemical properties are found in regressive and pearlless antler groups. These light-colored antlers, devoid of trophy features, had broken ends and poorly formed beams. It is difficult to associate this type of anomaly with 
the high concentrations of mineral elements $(\mathrm{Ca}, \mathrm{P}, \mathrm{Mg})$ and the high specific gravity that were observed in these antlers (Tables 1 and 2). In properly formed and partially malformed antlers, higher calcium and phosphorus content was found in the upper parts than in lower parts of beams and the opposite was true of nitrogen. However, the differences were not statistically significant. A tendency for calcium content to increase towards the apex was also noted by Samiullah and Jones (1991). Decreased amounts of organic compounds towards the apex result from an increase in highly mineralized compact bone content.

An analysis of heavy metal content $(\mathrm{Cd}, \mathrm{Pb}, \mathrm{Zn}, \mathrm{Fe})$ was done on samples used for this study, but it failed to answer clearly whether they can be linked causally to malformation (Sawicka-Kapusta et al. 1991).

Antler formation is influenced by environmental and intrinsic factors. Attempts to distinguish the contributions of these factors are difficult, requiring more data and larger amounts of material for comparison.

\section{References}

Bernard R. 1963. Specific gravity, ash, calcium and phosphorus content of antlers of cervidae. Naturaliste Canadien. 90: 310-322.

Bubenik G. A. and Bubenik A. B. 1990. Horns, proghorns, and antlers evolution, morphology, physiology and social significance. Springer Verlag, New York: 1-562.

Chapman D. J. 1975. Antlers - bones of contention. Mammal Rev. 5: 122-172.

Jaczewski Z. 1981. [Antlers of Cervidae]. State Agriculture and Forestry Publ., Warsaw: 1-253. [In Polish]

Pielowski Z. 1988. [Roe deer]. State Agriculture and Forestry Publ., Warsaw: 1-293. [In Polish]

Ruszczyc Z. 1963. [Principles of animal feeding]. Polish Sci. Publ., Wrocław: 1-267. [In Polish]

Sachs L. 1984. Applied statistics. A handbook of techniques. Springer Verlag, New York: 1-707.

Samiullah Y. and Jones K. C. 1991. Deer antlers as pollution monitors in the United Kingdom. [In: Global trends in wildlife management. B. Bobek, K. Perzanowski and W. Regelin, eds]. Trans. 18th IUGB Congress, Kraków 1987. Świat Press, Kraków - Warszawa: 415-420.

Sawicka-Kapusta K., Dudziński W. and Cichońska M. 1991. Heavy metals concentrations in roe deer antlers from Rogów (Central Poland). [In: Global trends in wildlife management. B. Bobek, K. Perzanowski and W. Regelin, eds]. Trans. 18th IUGB Congress, Kraków 1987. Świat Press, Kraków - Warszawa: 421-424.

Suttie J. M. and Fennessy P. F. 1991. Growth promoting hormones and antler development. [In: Global trends in wildlife management. B. Bobek, K. Perzanowski and W. Regelin, eds]. Trans. 18th IUGB Congress, Kraków 1987. Świat Press, Kraków-Warszawa: 283-286.

Szczepaniak W. 1985. [Methods of instrumentation in chemical analysis]. Polish Sci. Publ., Warsaw: 1-557. [In Polish]

Ullrey D. E., Youatt W. G., Johnson H. E., Cowan L. D., Fay R. L., Covert W. T., Magee W. T. and Keahey K. K. 1975. Phosphorus requirements of weaned white-tailed deer fawns. J.Wildl. Manage. 39: 590-595.

Received 29 July 1993, accepted 17 January 1994. 